\title{
Political-Party Neo-Centralism in the Italian Local Context
}

\author{
Antonello Canzano \\ Universita' Di Chieti, Pescara, Italy \\ Email: antonello.canzano@unich.it
}

How to cite this paper: Canzano, A. (2018). Political-Party Neo-Centralism in the Italian Local Context. Advances in Applied Sociology, 8, 517-533.

https://doi.org/10.4236/aasoci.2018.87031

Received: May 18, 2018

Accepted: July 9, 2018

Published: July 12, 2018

Copyright (C) 2018 by author and Scientific Research Publishing Inc. This work is licensed under the Creative Commons Attribution International License (CC BY 4.0).

http://creativecommons.org/licenses/by/4.0/

\begin{abstract}
This paper analyses the neo-centralism in the Italian polical party, the analysis regards the local contest. Its goal is to describe the Italian parties' evolution, in their organization and functional aspects. After the end of the mass parties, one could ask this question: "what happened to the most important political subject that dominated the Italian political system from the birth of the republic until the beginning of the nineties"? This paper aims to give a contribution to the understanding of the party de-structuring phase and the temporary structural reconstruction one. Despite the changes that have taken place, the political party continues in different ways to be central in the local and national context. How? The approaches are profoundly different from the past, they invest both the decision-making process of public policies and the selection of the ruling class at all levels.
\end{abstract}

\section{Keywords}

Political-Party, Neo-Centralism, Local Contest

\section{Introduction}

This article aims to elaborate the hypothesis of an updated political centrality and its main actor, the political party, in a context of profound weakness of its central and peripheral structures, proceeding towards the marginalization of some of the structural elements of the democratic system. This is analyzed using one of the most important variables at the base of a political system's general transformation process: the evolution of the political parties. Focusing on the transformation of the political parties in order to reflect the changing processes of the democratic system is suggested by the fact that this model was traditionally considered as a "party democracy" (Wright, 1979) initially characterized by a polarized multipartitism favoured by the pure proportional 
electoral system.

The national political system was defined by Tarrow (1979) in terms of a party subculture. This has implied for many decades that the pressure of politics on society is determined by and large, by the influence of political parties. If the systemic centrality of the party guaranteed a certain functioning of Western democracy, given the essential functions of social integration, participation and interconnectedness in a general manner between the society and its emerging State, today the organizational evolution of the old parties and the birth of new ones have significantly contributed to modify these functions and, with them, the weight of politics in society, affirming a sort of neocentralism of politics which is no longer founded on party mediation, but on an extensive patronage activity promoted by "entitled" personalities from within the party affiliations. They are facilitated by a "weak" organization of society (in terms of social cohesion) that leads to the enfeeblement of the internal decision-making processes of the state's organizations (e.g. bureaucracy, civil service, and judiciary) and makes the control over the work of managers of state enterprises, and of elected representatives rather effective.

Therefore, the neocentralism, born by virtue of the systemic centrality of the party both at the national and local level and which allowed the domination of all the other actors of the political system and the control of the national and local decisional processes, today it is characterized as a form of new "personalized" domination by political actors who only instrumentally exhibit their party membership.

We will try to reconstruct initially from a theoretical point of view, the long organizational evolution of the political parties and then we will examine the specific evolution of the Italian case with particular attention to local politics in which it is possible to observe the direct relationships between citizen, party and State, since it is possible to observe the role of politics in society through a sociological lens, focusing on the local community dimension. The place occupied by the parties within the social system, despite substantial organizational impairment, is hardly less relevant than before, even if the role exercised is completely different in nature and, for certain aspects, is even amplified in strength by laying the foundations for a renewed political centralism, disengaged from an effective relationship between citizen and State which, first in ideological terms and then in general terms, the party performed.

The centralism that the parties exercise within the Italian political system goes through all three phases characterizing its evolution: both in the phase of establishing and consolidating the democratic system, and in the next phase of deideologization and secularization; finally, in the phase of deconstruction that we can say still lasts today in the absence of a stable reconstruction of the party system. Neither the various configurations of the political framework in each of the three phases has significantly weakened the power of centralism and today of party neocentralism in the form of personalization. 


\section{Notes on the Organizational Evolution of Political Parties}

From Duverger to Karz and Mair, through Kirchheimer a long literature has described the organizational evolution of political parties in relation to the evolution and change of social systems. Different typologies have been developed taking into account the habitat from where the party was called upon to act and interact with other parties, and with various aspects of the polity and the social system. The organizational model that had greater affirmation and diffusion, often emphasized and mythologized during the twentieth century, has been the mass bureaucratic party, a party called organizationally to respond to the new political demands posed by the mass society, when the old parties showed themselves to be inadequate. The mass party, by its nature and vocation, was in fact oriented to the political socialization of the masses who knocked on the doors of the political system and, therefore, its organizational structure had to assume an inclusive and participatory dimension to: a large membership; structures composed of parallel and flanking social formations; bottom to top decision-making processes; and members' internal participation.

To this model described by Duverger (1961), Kirchheimer adds a new one that analyzes the mass political party crisis, in view of its deterioration. Kirchheimer's approach is very different from the Duvergerian one based on more functional and organizational analysis criteria. Indeed, the Kirchheimer's organizational plan focuses on the two aspects concerning the quantitative and decisional resizing of membership and the leading groups' exponential increase of power and of their role.

These organizational transformations depend largely on three decisive characteristics which intervened in the second half of the last century and which concerned the process of de-ideologizing, of overcoming the unidimensionality of the representation recognized by pressure groups.

With this shift in the organizational framework of the party, the relationships between parties, State and civil society change significantly.

In the mass party the integration of the masses in the political system was a primary function, and this process used as strategic resources the organization's large numbers in collective action. Thus the burgeoning party aims towards maximizing the immediate consensus, to be obtained by making the programmatic offer of policies, more rational and flexible.

The task of the mass party was not to elaborate a summary of national interests, but to act for the benefit of the represented class: in this conception of politics the relationship between the party, State and civil society foreshadowed a clear separation between State and civil society and the parties in the middle having a bridging and connecting role.

Therefore, the mass party, even penetrating the State and activating systems of patronage occupation of public offices, remains well anchored in civil society. So, the task of the catch all party will not be to organize a homogeneous membership aimed at reflecting the elite class but to recruit members following a po- 
litical programmatic identification, and not on the basis of a narrow social identity; nor will the party seek to recruit a particular section of the electorate, as everyone is a potential voter.

Therefore, the strategic dimension once assumed by membership in the catch all party will become the favored style of political communication through the development of mass communication systems, and this new party will communicate directly with the voters. The evolution towards the "pigliatutto" ("big tent") party entailed a profound change in the relationship between party, State and civil society. Thus the party is not a civil society agent who acts on the State and penetrates it, but an intermediary between the civil society and the State. If the mass party is a mediator by contrast of the class, the catch all party is a pure and simple all-round mediator, who tries to satisfy the independently organized interests.

Within this new relationship there are also changes, since the relationship of the citizen with the party is becoming more intermittent and limited to precise and delimited areas [...] the individual relation to politics is both tangential and discontinuous (Kirchheimer 1966: p. 198).

But, as we said at the beginning, the explanation of these phenomena must be sought in the external social habitatus of the parties, and not within them. In fact, the social transformations that have taken place in Italian society have deeply changed the relationship between citizens and politics: if the mass party reflected the industrial society in its main characteristics, the catch all party will reflect its disarticulation and entry in post-industrial and post-modern society.

Katz and Mair (1995), also approaching a new organizational model, consider the evolutionary stages as something dynamic linked to social transformations and see in the new role of the mediator party par excellence the germ of its transformation. First, because the party as the holder of the mediation between civil society and the State may have "interests distinct from those of their clients on either side of the relationship" (Ibid.); second, because the ability in the mediation depends not only on the ability to address the electorate but also on the ability to manage the State, "but if a party can handle the state in the interests of its civil society clients, it should be able to manage the State in its own interest" (Ibid.), then very easily the parties will use the electoral power obtained to protect their interests. Starting from these premises our authors describe an evolutionary dynamic that sees the party moving from civil society towards the State, in order to become part of the same State apparatus, at some point along the way. Katz and Mair come to this conclusion by reflecting on the organizational transformations and its consequences on the ability to find financial and material resources, which today, with the general weakening of the organization and the growth of party activity costs, may be found in large part only by the State, transforming the party into a public service enterprise.

The development of the cartel-party, as this new model is defined, is in fact characterized by "the interpenetration between party and State and also for the 
development of a collusive plot between the parties themselves" (Katz \& Mair 1995, 17) and is connected with the modified relations between society and institutions. If the main occupation of the party, from the perspective of the cartel-party, is the hoarding of public resources it will inevitably overshadow its function of connection and of social representation at the State (Ibid.).

This process socially overlaps with that postmodern characteristic defined as social atomization (Bauman 2001) without underestimating the inherent social consequences in the process of globalization. But even more important is the new role acquired by the State and the symbiotic relationship that it has been creating with the parties cancelling almost completely every different ideology, and establish an identity through a process of homogenization.

From this briefly described process emerge two aspects with greater relevance, and with abundant consequences for understanding the political process of modern states, including Italy: the process of de-ideologization and the different relationship the parties establish with members and institutions (Ignazi 2004).

If the de-ideologization has inevitably loosened the link between citizen and party and the individualization of society has greatly reduced the parties' capacity for mediation and of representation, this did not result in a reduction of their influence on the public decision-making processes. The parties even came out strengthened by the threat of downsizing so that, at some point, the new social movements and organized pressure groups emerged (Ibid.).

The parties, according to Ignazi, are now even stronger. It is a verticalized force obtained precisely at the memberships' and supporters' expense (Ibid.).

They are not only holders of deputation but have, through a renewed patronage activity, almost absolute power over public appointments, the power to adopt any particular measure at a national and local level, and can establish relations of authority through the legitimation of the new party's leader.

The new patronage derives precisely from that relationship now assumed by the party with the State, exactly as described by the cartel-party theorists.

\section{The Party Centralism in Italy}

The Italian party system was largely institutionalized by the early sixties; its consolidation and stabilization were established by the low rate of electoral volatility (Morlino 2006: p. 106). The three largest parties had, in different ways, reached a high level of organization. In order to describe the organizational reality of the three parties we refer to two different mass party models: the denominational one named by Newmann describing the or DC (Democrazia Cristiana); and the social integration one describing the PCI (Partito Comunista italiano); the PSI (Partito Socialista italiano), as well as the MSI (Movimento Sociale italiano), had not succeeded in setting up a mass organization (Newmann, 1956; Tarchi, 1997). In fact, the Fanfanian reorganization of Democrazia Cristiana started in 1954, tending to create a modern mass party widely spreading at a peripheral level, yet did not being fully successful; and, in some ways, achieving 
different results from those expected, given the inescapable dependence of the party from the collateral organizations of Catholic origin and, subsequently, also from the organizations of the public bureaucratic apparatus.

This consolidated dependence had the effect of strengthening the internal factions, mostly autonomous, which in fact prevented an effective centralization and favored a weak internal structure (Morlino, 2006; Newmann, 1956; Tarchi, 1997). The PCI (Partito Comunista italiano), defined also by external legitimacy (the third international) and with a strong role of collateral organizations, differed organizationally from the DC (Democrazia Cristiana) in its degree of centralism which was fundamental in this case, given the membership's decisive role, as it was considered its main resource. Same collateral organizations were not a disaggregating factor as they were in a subordinate relationship with the party (Biorcio, 2003: p. 53). The PSI (Partito Socialista italiano), as we said, despite the Morandi's efforts, never succeeded in assuming an organizational dimension such as to become an integration party In fact, it was characterized by a reduced number of militant members and a minor support from collateral organizations (Morlino, 2006: p. 106). Regarding Pri, Pli, Psdi (minor parties), they presented a very weak organizational framework with a small number of members and personal and with a strong role of local leaders; finally, the MSI had an organization structured by sections, provincial federations, central committee, national secretary with a strong leadership, and with collateral organizations, mainly of students; nonetheless, no similar apparatus ever succeeded in becoming an instrument of integration nor an aggregation pole (Ignazi, 1998: p. 253).

Here, what is most important to stress is that the vote's stabilization, both organizational and structural, at least until the early $70 \mathrm{~s}$ of the last century, allowed the three major parties, including the DC (Democrazia Cristiana), and PCI (Partito Comunista italiano ), with their highlighted differences, to be parties of "Social promotion" and, "institution connection between political class and social reality, for the fact to perform the function of "promotion vehicle" of certain social classes" (Galli, 1966: p. 175).

The two major parties gathered two thirds of the electorate: the Democrazia Cristiana exercised a quasi-monopoly of interclass connection; and the PCI (Partito Comunista italiano) extended, by the mid70s, its representation to other classes along with its persistence of long-term political guidelines, its direct and indirect aggregative capacity and the formation of territorial political subcultures. In fact, "The hegemony of the two main Italian parties was not only political, but also cultural and organizational" (Biorcio, 2003: p. 69).

The main elements of this hegemony were attributable firstly to the relationship between parties and religious organizations, in particular those between the DC (Democrazia Cristiana) and Catholic organizations; then to the particular relationship between parties and individuals, or non-organized civil society groups; and finally to the relationship between parties and interest groups, in particular associations of entrepreneurs and trade unions (Morlino, 2006: p. 
113). Yet beside all this, the two main parties represented the two traditions of popular culture born at the end of the nineteenth century (Alberoni, 1967: p. 19).

These two different cultural traditions, together with the various socio-economic subsystems, enabled the formation of real territorial subcultures that would influence the ballots, in the long term. Traditionally the Democrazia Cristiana was rooted in the Northeastern regions and the PCI (Partito Comunista italiano) in Central Italy.

In areas where politics is so deeply rooted that it is also a strong family tradition [...] in which the integration between family and environment, in terms of the image of society, behavior patterns, socialization process, is very high, the dominant parties base their own power on the perception of the attitude towards the vote, as an attitude acquired and not modifiable except in exceptional circumstances (Galli, 1968: p. 320).

There is an inseparable bond between party, territory and society; the society's and territory's organizations, the local ideological and religious traditions will be fused with both parties' representation, whether at the level of the local power as well as in relationship with the central power.

More than a distinct entity, politics is part of the local world. It configures the government, often it constitutes and structures the services and the associative life as the mass parties [...] constitute an essential reference (in the red zones) of the Community's network (Diamanti 2003: p. 19).

In the Northwestern regions there is no such bond and there is a high level of competitiveness among the parties. The South, generally has a high degree of instability between parties and electoral fluidity. Obviously, the reasons for instability are different because, if for the Northwest the identity factor is weakened by the opinion and interests having a greater pressure on the electoral tendencies for the South, the fragility of the socio-economic fabric will greatly favor the local leadership groups at the votes (Ivi, 25-26).

The territorial political subcultures are supported by the socio-economic localism that incentivizes growth and development.

Thus, in these areas, they vote by a conditioned reflex, in order to confirm a sense of belonging, an identity, to promote and consolidate localism. And the parties, compared to this world, present themselves as factors for recognition, representation and consolidation. It is about two parties immersed in society and in institutions. Society parties and institution parties at the same time (Ibid., 34-35).

\section{The Public Policies}

Although the local politics has been mostly characterized by a low level of politicization and therefore more is pragmatic than ideological, in Italy, instead, more so than elsewhere, and the processes for the establishment of local public policies have suffered in a decisive way in the erosion of political culture, for long pe- 
riods. We assert, therefore, that local political cultures have profoundly shaped the local government's action, in terms of the constraints posed by the relationship between parties, administrators and social groups, as well as in terms of the possible responses to environmental changes.

Electoral results depend, to a large extent, on the specific nature of the polarization and: ... to understand how local government works in Italy, we must take into account how the relationships between individuals and groups and transmission of demand diverge, as do the management of administrators and perception of institutions by social subjects, the use of institutions and resources, attitudes and expectations. The comparison is marked not just between metropolitan areas and provinces, but also between red and white areas, between North-east and North-west, between Center and South (Caciagli, 1986: p. 15).

To better understand the local politics it is necessary to refer to the criterion of competition for power, as it is believed that:

...there are substantial and convincing elements to support the hypothesis that in structuring the local political competition the parties and their apparatuses, the political culture promoted by them, the historical fractures, institutional characters, etc, play an ordering role, these variables mostly explain the typology of the actors involved and the modalities of interaction between them, as well as the characteristics of the political processes that are structured around the policies (Baccetti, 1999: p. 7).

The competition for power, however, also suffers particularly from the resources available to them on the periphery, and it is legitimate to say that these resources contribute to defining the type of local politics, especially with regard to our case, labeled as a model predominantly oriented to the mobilization of political support by the leadership (Page. 1981: p. 146; Goldsmith 1991). The main features of this model are evidenced by the acquisition of consent through the mobilization of local politicians, by the use of consent to influence national decisions on resources to be locally allocated and by the strong role of the local elite in business deals and negotiations.

More generally, a more useful classification of local public policies for the Italian model could be the one proposed by Baccetti, which addresses the elements:

1) to the distribution of resources and benefits for individuals or particular groups of individuals, 2) to expand the accessibility of social rights through the provision of redistributive services to the most disadvantaged sectors of the population; 3) to promote economic growth, ensuring better conditions and reducing the constraints of market forces, 4) to respond to a structuring of local conflicts around environmental issues and post-materialistic, in a broader sense, prompted by an innovative and recent social demand; 5) to reproduce at a local level the structure of the competition/conflict between center and periphery, both in symbolic and cultural terms (Baccetti, 1999: p. 5-6).

That said, the distinctive element that is most interesting to highlight here is 
the strong party nature of local politics, a key to understanding the role of elites and distribution of power in local government, as well as in explaining the genesis of local public policies and their characteristics in terms of formulations and outcomes. The strong party nature of policy making saw the party at the center of relationships involving administrators, lobbyists, bureaucrats. This was translated, at least in the most relevant policies, by the overlapping of roles between party personnel and political-institutional ones, and by handing positions to the same people. The outcomes depended on the peculiarity of the relationship between the party members and on the degree of maximization of consent, deriving from the fulfillment of particular expectations:

It is the inter-party and inter-party dynamics that ultimately make the difference in opening or closing the excess to the particular interests, with the implementation of the inter-institutional relationship between center and periphery and with the overall coordination of the actors involved in the various procedural stages, and it is always the figure of a politician-administrator head of a party whether he succeeds or not who takes the role of process regulator (Baccetti, 1999: p. 9).

Party-centrism in the local exception does not, however, translate into a strong capacity to elaborate programs in almost all areas of public policy, delegating this function to the "Assessor" for general policies, or to the "expert politician" for those highly-technical policies:

Today it is the councilor who, in an autonomous form, defines the policy of his council and eventually suggests to the party the line to have towards the public opinion on specific matter (Bettin \& Mannier, 1991: p. 302).

The local administrators, once elected, find themselves faced with the party's low capacity to formulate the programmatic lines and to give the electorate answers (Segatti, 1992: p. 69). In some researches conducted in the eighties, there are hints of how the parties already considered crucial, and therefore the party's central prerogative, two phases of the local political process: the pre-electoral phase in function of both the identity and the aggregation of the peripheral instances towards the common national line, which approved by the coalitions of local governments; and in the second phase, on the other hand, the formulation of the local political agenda, which seemed less interesting to the parties than their own "Centralized management of fragmentation", leaving the various policy choices almost entirely on the margins. Our authors highlight that in this context:

We are not in the presence of a similar "centralized management" of the electoral programs, nor of a management on top of the local administration's work [...]. We could say that the party's leadership is mainly interested in "with whom" they rule in the periphery, not "how" nor "what for": this is the norm, which also applies outside the elections (Getting, Girotti, \& Bonet 1984: p. 376-37).

From the end of the seventies onwards, the interest of most parties is to par- 
ticipate in the local government, even in heterogeneous ways, in order to remain inside, leaving the how and the what to do in the local governments to the autonomy of the peripheral political class (Ivi, 379). This autonomy, in its weak local political-programmatic system of national parties, is essentially carried out in the infra-party arena both in terms of policy formulations and decision-making processes.

Ultimately, the party's local internal processes determine policy choices.

The party actors therefore play their resources on multiple arenas, but in the meantime they will have more possibilities to prevail and to control the policies as they will be individually strong in the infra-party arena (Baccetti, 1999: p. 14).

Furthermore, the prerogative of public policy formulation by local party elites is to be understood as strategically functional in order to increase the internal power of the party (Mulè, 1995: p. 196). In this perspective, the competition between the internal party elites determine the public policies and not their content; to this is added the fact that:

It is within the parties and not elsewhere that were structured the relations between government and local government and with sectors of society, groups and interests involved in the process. "Inside the parties" means in the struggle for the control of the local leadership, in the relations established between the elite placed at different levels of the party structure and in the use that this local elite makes of the organizational resources (Baccetti, 1999: p. 18).

Also in the hypothesis concerning "the entrepreneur policy" the representative of the local elite cannot renounce the institutional "charge" deriving from the organization in order to exercise its role, at least in the form of selection and recruitment, held by the political parties (Canzano, 2012).

Also in the elaboration of public policies, as we have seen, the hypothesis of the political party neocentralism that follows the evolution of the party subject is confirmed, becoming today no longer in the form of traditional Gatekeeping, but in the forms that the different parties within the parties intertwine first with the local Lobby and then with separate groups of civil society that are linked to them in various ways. Precisely in this context the activity of Patronage takes on greater strength and tends to become the regulating principle of the distribution of interests at the local level.

\section{The Transformation of the Party Subject in Italy}

Rather than having to retrace the entire process of transformation of the Italian party system, we will rather try to grasp some effects on the peripheral aspects of the Italian political process, which has some explanatory value.

We have seen how in the ' 70 s there were some significant changes in the Italians' electoral behavior, which developed over time. A significant change manifested itself with the administrative vote of 1990, which sanctioned the Lega's ratification; later the referendum on the unique preference undermined part of the consolidated consensus-gathering mechanism; finally, with the political vote of 
April 1992, the so-called "different vote" took on dimensions that initiated to have a deconstruction in the character of the electoral process (Sani, 1992: p. 540).

In fact, the elements that defined the structures of the electoral market, which faltered as a result of the appearance of new forces capable of aggregating a significant consensus, are those that engineered substantial social changes. Other important elements of change which emerged were: breaking through of new cleavages into society, following the weakening of those that traditionally were part of the Italian society one in particular is identified in the new center-periphery fracture between the "North and the State" (Diamonds, 2003: p. 65): a progressive de-alignment between political forces and organized social forces, which have broadened the opportunities for consensus of new political actors; the weakening of the traditional party identifications and, as we have seen, of the incidence of subcultural affiliations; the partial delegitimization of traditional political forces (Sani, 1992: p. 541-543).

The most important changes occurred between 1991 and 1994, and the first party to enter the crisis was the PCI (Partito Comunista italiano)) that began a long and conflict-laden transformation process which is ending, perhaps, only now with the establishment of the Democrazia Cristiana. The crisis manifests itself above all with the collapse of electoral consensus, which already started in 1979 and which would continue during the following years (with the exception of the European vote in 1984), even after the establishment of the PDS (Partito Democratico della Sinistra), which yielded about a third of the votes to the Communist Refoundation Party, immediately after the split. The party's membership suffered a further decline in the early 90 s and adding to that:

The organizational inadequacy and strategic ambiguity, however, can be considered at the origin of the decline of its electoral circumstances and the inability of the party to redirect its own ties with civil society. The result was a retrenchment of the local interests and consequently a progressive pulverization of that structure and party that had appeared so monolithic in the past (Morlino \& Tarchi, 2006: p. 128).

The focus on local interests also derives from the fact that this Party's constant commitment to the periphery was justified in consequence by its perennial exclusion from the national government, that led to legitimize itself as the "Party of Local Administrations" that would not be much affected by the disaffection towards the central State, and it would therefore not be so much invested (ideologically or structurally) in the new one center-periphery fracture (Diamanti, 2003: p. 51). Moreover, its further local refolding also derives from what Diamanti has called the Partito Democratico della Sinistra-Democratici di Sinistra "organizational persistence", in the "red" areas, and "above all the associative network connected to the left and, even more, the local governments, continue to "guard" the territory and reproduce the local consensus" (Ibid.).

The crisis of the Democrazia Cristiana reached its peak in 1992-1994 due primarily to the erosion of the consensus, and above all the one traditionally ex- 
pressed in the "white" (North East)] areas, due to the effect of the new electoral laws and, finally, for the Mani Pulite investigations (judicial inquiry against corruption).

The new electoral law as a strong Majoritarian accentuation resulted in what is called the "early reaction" of the political leaders.

Even before March 1994 when it was expected that the first elections were held under the force of the new law internal divisions had led to the split of the DC into several groups, in an attempt to anticipate a bipolarizing impact, and therefore would have had the new law election (Morlino \& Tarchi, 2006: p. 131).

The judicial factor linked to the investigations of Mani Pulite, whether for the inquiries themselves or, above all, for the impact that this imposed on the public opinion produced a strong delegitimization of traditional political parties.

In the case of the Democrazia Cristiana (DC), however, a local refolding was not possible, not only because the Partito Popolare italiano (PPI) was not the DC's sole heir, able to propose itself in the old white areas as a follower of that history and that tradition, but mainly because the new center-periphery conflict, with the birth of a "new political entrepreneur" (Biorcio, 2003: p. 133) like the Lega, assailed the Democrazia Cristiana not only as a State-party, but as a State now considered distant and hostile, especially as a party that was no longer considered a referent, even with its transformations, to the new needs, new interests and new values expressed by a territory, which now sought new forms of social and political representation.

In this context, one of the significant changes is the decline in the presence of the major parties in civil society, which led to the end of the mass party (Morlino \& Tarchi, 2006: p. 135). Additionally, the parties' membership, new and renewed was shrinking, for the same reasons that were at the basis of the declining capacity for mass recruitment. The new parties such as the Lega and Forza Italia chose not to follow the model of the mass party. The "post" parties, more by necessity than by choice, contributed to give life to the Partito Democratico (PD) and Popolo della Libertà (PDL), renouncing definitively the traditional model of social integration. The result, overall, was the receeding of the parties, in contrast to the strong social foundation that had distinguished them during the First Republic. The de-ideologization and secularization, weakened the relationship between parties and society and, as a consequence, it saw the progressive de-alignment between parties and social forces: the unions in the 90s became more and more autonomous, if not completely independent of the ruling party. Confindustria (Associazione di Categoria degli Industriali) is a now an autonomous actor, intermittently shifting its closeness to the center-right, but basically oriented to the multiparty plea, which prevailed also for many organizations and social formations, which were previously tangential.

The entire patronage system started to fail, as it was founded mainly on relationships with the regions, and with social groups, after the reduction of the parties' distribution capacity and their diminishing power to force decisions that 
were beyond democratic control, being more and more the prerogative of European Union structures. The consequence of the breaking of the ties between parties and society inevitably reflected on the degree of trust citizens placed on the local political parties, which today capture only some $5 \%$ of the electorate (Demopolis 2013). Not only the external but also the internal bonds constraining the political parties have loosened, compromising these hierarchical relations between center and periphery that guaranteed their previous coherence and organizational stability.

Today, the layering relationships, with their consequent autonomy at different internal levels and, in particular, peripheral ones, tend to prevail (Mair 1994, 17). Some consequences of this process, observable in our local reality, can be, on the one hand, the almost total lack of interdependence between national and local levels with the risk of mutual isolation; and, on the other hand, the transformation of local franchised parties using a national brand, yet distributing a specific product to the different local markets (Carty 2006, 87).

\section{The Current Trend}

At this point, despite the ongoing processes that affect the Italian politics and its transformation dynamics, characterized by a considerable fluidity, we ask ourselves if the parties, despite their crises and their current search for consolidation, are still able to mediate benefits; or, rather, are there other actors (from the European Union) performing these tasks. It is a matter of considerable interest and cannot be treated by observing and analyzing individual decisions, as important as they may be, since it sanctions the relationship between party and society, between parties and social groups in all their complexity. The general opinion about the relationships, especially between parties and groups, is that the political weakness often gives greater power to pressure groups (La Palombara, 1994; Pirzio Ammassari, 1997), rather than gaining ground in decision-making positions. Yet, stating this is quite different than supporting the expropriation of the parties' control on decision-making processes, as they would lose every ability to mediate benefits. In the processes of local political groups, internal consultants, technicians, etc. have undoubtedly a greater capacity for autonomous access and representation, but this does not translate automatically and in all contexts, into a new dominance by other actors. Perhaps the problem should be posed in a different way, since today the mediation of benefits is conducted in a general redefinition of roles imposed by governance processes.

The research conducted so far on local politics, does not reveal that public administrators and party leaders are being replaced as mediators in decision-making processes, replaced by external figures, mediation professionals who have imposed themselves after the processes of de-politicization (Baccetti, 1999: p. 32). The reality seems to confirm, however, the parties' centrality whenever decisions concerning public policies occur.

However numerous may the "intrinsic" actors involved in the process and 
however crowded and open may the policy making be, it is the information flowing between the parties that are competing for the access and control of the decision-making power in institutional contexts which finally define the processes and determine the outcome (Ivi, 11).

The relations of cooperation between parties and groups, between parties and experts are certainly intense and frequent. Indeed, their relationships are increasingly close and, given the parties' objective weakness, external technical-programmatic support is more and more frequent, without forgetting that this partly happened before the destructuring of the party system, considering, as we have seen, the poor programmatic capacity of the parties. This does not mean that party politicians do not continue to monopolize the inclusion of the most relevant public policies into their agendas but only through their agreement is it possible to start a public policy program by the direct management of mediation (Ivi, 13). At this point, it is perhaps legitimate to ask whether local politicians are still political entrepreneurs, or rather are they the peripheral agents of national bosses without significant territorial links. If they are still political professionals, given the temporality of their careers, are they always less defined and perhaps even less and less providing actual careers (Bettin \& Mannier, 1995). This, it is evident, will have consequences on how the decision-making processes are conducted and on which criteria the individual contents are regulated.

One thing is certain, when determining policy choices, individual political actors operate within increasingly competitive and fragmented arenas, starting with the party itself and the coalition. If the characterization assumed by the local political system is above all the high "conflict" rates within the party and the coalition, it will be increasingly difficult to mediate on specific subjects, such as, for example, territorial policies, where the competition of interests is particularly high.

New elements have also contributed to modify the modalities for the aggregation of interests, such as the introduction of the mayor's or regional council president's direct election which have in some ways constituted, for the past twenty years, a factor for the reconstruction of these competitive arenas. In the electoral arena, mayors constitute an "autonomous factor for the structuration of the vote, to the detriment of the much weaker parties" (Di Virgilio, 1999: p. 73; Canzano 2013).

Their government prerogatives are so large that it is becoming increasingly difficult, in a context of fragmentation and high conflict, to recover the parties' past roles. From a more general point of view of the new local political elites, a further important problem remains unresolved: the selection of the new administrative elite. This happened during the transition from the old to the new political system and has not found a real solution in over twenty years: in fact, the issue carrying the most political weight occurs when determining the local policies' problem of training personnel for public offices.

Finally, the current fragmentation and conflict within the party framework seems to favor the neocentralism of the new local political elites who, taking ad- 
vantage of the internal organizational weakness of the parties, impose a different way, in the perspective of the Patronage, a different way of regulating interests and distributing resources.

\section{Conclusion}

We have seen how the party system in the period of democratic consolidation and until the end of the seventies was expressed in the form of polarized multipartitism or, better said, polarized pluralism (Sartori, 1967: p. 1-34); subsequently with the introduction of the majority (1994), we passed to a bipolarism equally polarized with a large party fragmentation inside the two poles; today following the election of March 2018 with a prevalently proportional system there is a sort of imperfect tripolarism with little capacity to form coalitions and keep them alive. All this has happened in Italy thanks to the change in the elements that define the level of structuring of the electoral market, starting from the stability of the electoral offer that falters following the appearance of new forces capable of aggregating a significant consensus. Important elements of change have emerged: a progressive de-alignment between political forces and organized social forces, which have widened the opportunities of consensus for the new political actors; the weakening of traditional party identifications and, as we have seen, the incidence of subcultural membership; the partial delegitimization of traditional political forces; the break in the society of new cleavages, following the weakening of those that traditionally have gone through the Italian society, one in particular is identified in the new center-periphery fracture determined by the policies of the European Union that leads to identify the center with the elites of Brussels, so far and not legitimate.

The new situation, which is also due to the irruption of the Movimento 5 stelle in the political scene, still seems far from being stabilized. What emerges is the opening for the new political subjects of new training areas and new structured accesses (groups, movements, lobbies) alternative or parallel to the parties themselves. In conclusion, the current process suggests not so much a reflection in terms of the retreat of politics or parties, to the benefit of "society" or "professions", despite the Movimento 5 stelle's attempt to introduce personnel unrelated to political professionalism, but rather, a broader rethinking on the type of political system that is being configured, which despite the significant changes occurring, still sees the party and, better said, its representatives in positions of power at the center of the scene and the epicenter of political interaction.

This is more highlighted at the local level where the whole of reforms in the majority sense of the 90 s will always contribute to modifying the center-periphery relations, but above all they will help to redefine the role of the parties both as unique mediators of the consensus, and as solitary selection agents, recruitment and legitimacy of local representative politicians. These last ones will be those who will support the political party neocentralism. 


\section{References}

Alberoni, F. (1967). L'attivista di partito. Bologna: il Mulino.

Baccetti, C. (1999). Poteri locali e politiche pubbliche. Torino: Utet.

Bauman, Z. (2001). Dentro la globalizzazione. Le conseguenze sulla persona, Laterza, Roma-Bari.

Bettin, C., \& Mannier, A. (1991). Chi governa la città? Padova: Cedam.

Bettin, C., \& Mannier, A. (1995). I nuovi sindaci: Come cambia una carriera politica. Rivista italiana di scienza politica, 1, 111-117.

Biorcio, R. (2003). Sociologia politica. Bologna: il Mulino.

Caciagli, M. (1986). Introduzione. In Arculeo, Baccetti C. \& Colasio (a cura di), Governo locale, associazionismo e politica culturale. Padova: Liviana.

Canzano, A. (2012). Sindaci e giovani sindaci. Dinamiche di trasformazione nella politica locale. Milano: FrancoAngeli,.

Di Virgilio, A. (1999). Quanta acqua sotto i ponti della politica locale? In S. Operto (ed.), Regole e attori del voto comunale quattro anni dopo, Votare in città. Milano: Franco Angeli.

Diamanti, I. (2003). Bianco, rosso, verde. Bologna: il Mulino.

Duverger, M. (1961). I partiti politici. Milano: Edizioni di Comunità.

Galli, G. (1966). Il bipartitismo imperfetto. Bologna: il Mulino.

Galli, G. (1968). Il comportamento elettorale in Italia. Bologna: il Mulino.

Ignazi, I. (1998). Il polo escluso. Bologna: il Mulino.

Ignazi, P. (2004). Il puzzle dei partiti: Più forti e più aperti ma meno attraenti e meno legittimi. Rivista italiana di scienza politica, 4, 325-366.

Katz, R., \& Mair, P. (1995). Change Models of Party Organization and Party Democracy: The Emergence of the Cartel Party. Party Politics, 1, 5-28.

Kirchheimer, O. (1966). The Transformation of the West European Party System. In J. La Palombara, \& M. Weiner (Eds.), Political Parties and Political Development Princeton, NJ: University Press.

La Palombara, J. (1994). Clientela e parentela, rivisitato. In M. Caciagli, I. Cazzola, L. Morlino, \& S. Passigli (Eds.), L'Italia fra crisi e transizione. Bari: Laterza.

Morlino, L. (2006). Le tre fasi dei partiti italiani. In L. Morlino, \& M. Tarchi (Eds.), Partiti e caso italiano. Bologna: il Mulino.

Morlino, L., \& Tarchi, M. (2006). Partiti e caso italiano. Bologna: il Mulino.

Mulè, R. (1995). Partiti politici e politiche pubbliche. In G. Regonini (Ed.), Politiche pubbliche e democrazia. Napoli: Esi.

Newmann, S. (1956). Modern Political Parties. Chicago: University of Chicago Press.

Page, E. C. (1981). Localism and Centralism in Europe: The Political and Legal Bases of Local Self-Government. New York, NY: University Press.

Pirzio Ammassari, G. (1997). L'Europa degli interessi. Roma: La Goliardica.

Sani, G. (1992). La destrutturazione del mercato elettorale. Rivista italiana di scienza politica, 22, 3 .

Sartori, G. (1967). Bipartitismo imperfetto o pluralismo polarizzato (p. 31). Tempi moderni.

Segatti, P. (1992). Crisi del governo di partito e solitudine dell'amministratore comunale. 
In R. Segatori (Ed.), Istituzioni e potere politico locale. Milano: FrancoAngeli.

Tarchi, M. (1997). Organizzazioni e strategie. Bologna: il Mulino.

Tarrow, S. (1979). Tra centro e periferia. Il ruolo degli amministratori locali in Italia e Francia. Bologna: il Mulino.

Wright, W. E. (1979). Due modelli di partito: quello razionale-efficiente e quello della democrazia partitica. In G. Sivini (Ed.), Sociologia dei partiti politici. Le trasformazioni delle democrazie rappresentative. Bologna: il Mulino. 